\title{
O "ATIVISMO SOCIAL" EMPRESARIAL E O SEU VIÉS ANTIDISSENSUAL ${ }^{1}$
}

\author{
Attila Magno e Silva Barbosa*
}

\begin{abstract}
Este trabalho consiste em uma análise da responsabilidade social empresarial (RSE) como um meio de supressão da política e esfera de manifestação do dissenso. A atuação de organizações como o GIFE (Grupo de Institutos Fundações e Empresas) e do Instituto Ethos de Empresas e Responsabilidade Social tem contribuído significativamente para a legitimação das ações de RSE como fontes produtoras de soluções para problemas sociais. Nesse sentido, entendemos que o fundamento ideológico dessa situação encontra-se em um discurso que visa a minimizar o papel do Estado como agente promotor de desenvolvimento social e atribuir aos pobres, como indíviduos, a responsabilidade pela permanência ou não na condição de pobreza. Tais práticas promovem o envolvimento dos beneficiados nas soluções de seus problemas, o que parece ser positivo do ponto de vista da criação de uma esfera de tomada mais democrática de decisões, todavia é preciso ter em mente que os saberes desses beneficiados só são considerados a partir de um esvaziamento do caráter de posturas efetivamente dissenssuais.

PALAVRAS-CHAVE: responsabilidade social empresarial, ativismo social empresarial, sociedade civil, novo associativismo civil, dissenso.
\end{abstract}

\section{INTRODUÇÃO}

Apesar do inegável fortalecimento do associativismo civil nos diais atuais, a faceta neoliberal da globalização estimula o exercício de uma cidadania esvaziada da possibilidade de falas efetivamente dissensuais. A democracia representativa está em perfeita adequação aos interesses da reprodução social do capitalismo, pois atribui ao voto o caráter de expressão máxima do exercício da cidadania. Aqui, a noção de igualdade está baseada no príncipio do "um homem, um voto", originária das revoluções burguesas de inspiração iluminista ocorridas no final do século XVIII. Não é por outro motivo que o sufrágio universal é entendido como a quintessência da democracia moderna. A força desse ideário ainda habita entre nós

* Doutorando do Programa de Pós-Graduação em Sociologia da Universidade Federal de São Carlos - UFSCar. Rod. Washington Luís, km. 235 - Cx.Postal 676 (Edifício do CECH). 13565-905 - São Carlos - SP - Brasil. barbosaattila@uol.com.br

${ }^{1}$ Gostaria de agradecer a meu orientador, professor Jacob Carlos Lima, pelo apoio dado a esse projeto, paralelo à minha pesquisa de doutorado, e à professora Cibele Saliba Rizek, pelo diálogo profícuo e inspirador, sem o qual os insights aqui contidos não teriam sido possíveis.
- menos vigorosa que no passado, é verdade, haja vista os modelos de democracia mais participativas que há tempos vêm sendo propostos. Entretanto, a persistência da hegemonia da democracia representativa nitidamente converte os indivíduos em meros espectadores das decisões políticas, já que as manifestações reivindicatórias dos grupos que se sentem sofredores de danos, no contexto de um projeto comum de sociedade, somente são consideradas legítimas dentro dos limites cinscunscritos pelas normas jurídicas que descrevem o que é entendido como dentro ou não da legalidade.

Por sua vez, o associativismo civil, principalmente das ONGs, não apresenta posturas efetivamente contra-hegemônicas, mas apenas corretivas dos danos causados pela lógica do capitalismo global. Ao mercado interessa um tipo de inserção social que ocorra pela via dos acessos ao crédito e ao consumo, e não pela via do exercício de uma cidadania crítica no contexto de uma esfera pública realmente ampliada. Desse modo, o Estado não é operacionalizado para promover igualdade e justiça social, mas sim para gerenciar necessidades não contempladas e carências não suprimi- 
das de indivíduos convertidos em uma massa estatisticamente seccionável e quantificável.

Isso posto, falar em responsabilidade social empresarial (RSE) pode parecer descabido, mas não o é, pois ela é apresentada pelo discurso de diversos atores sociais como um dos caminhos possíveis para a construção de novas formas de promoção de cidadania e de inserção social, não mais centradas na figura do Estado, mas sim nas chamadas parcerias intersetoriais. Um tipo de cidadania que elide a figura do Estado como esfera pública em que a vida em comum pode ser pensada e o converte em simples esfera de gestão de carências e necessidades de uma massa global de indivíduos que passa a ser gerida por um conjunto de técnicas que os reduz a simples estatística.

Tendo em vista os objetivos deste artigo, o conceito de política que iremos pautar baseia-se na definição de Jacques Rancière (1996a, 1996b), ou seja, a política entendida como reclamação da "parte dos que não têm parte" e, como tal, dissenso. Nesse sentido, a política se manifesta a partir da imposição mínima de uma agenda de questões por parte de indivíduos ou grupos sociais que se sentem sofredores de um dano e que ainda não estão constituídos como iguais na "partilha do sensível".

Denomino partilha do sensível o sistema de evidências sensíveis que revela, ao mesmo tempo, a existência de um comum e dos recortes que nele definem lugares e partes respectivas. Uma partilha do sensível fixa portanto, ao mesmo tempo, um comum partilhado e partes exclusivas. Essa repartição das partes e dos lugares se funda numa partilha de espaços, tempos e tipos de atividades que determina propriamente a maneira como um comum se presta à participação e como uns e outros tomam parte nessa partilha (Rancière, 2005, p. 15)

A imposição dessa agenda não implica necessariamente ganhos reais, mas possibilita o surgimento de um campo específico de lutas, no qual grupos antagônicos se vêem obrigados a se movimentar. Para Rancière, o que tradicionalmente se define como política ele define como "polícia", o que, em seus termos, corresponde ao conjunto de operações dos atores sociais dentro do campo político já instituído.
A nossa proposta consiste em fazer uma análise das ações de RSE à luz de uma perspectiva que leve em conta o viés antidissensual desse tipo de ações. Isso porque entendemos que a disseminação da lógica do "ativismo social" empresarial poderia ser percebida como uma estratégia promovida pelos agentes sociais do mercado no sentido de suprimir a política como esfera de manifestação do dissenso.

Ante esse quadro, nossa hipótese é de que as ações de RSE estão inscritas no conjunto técnicas de gestão operacionalizadas para o atendimento de necessidades e carências locais, e não para a viabilização de uma condição plena de cidadania, como alardeia o discurso que sustenta essa lógica. Para tal, nossa análise pauta-se nos casos do Instituto Ethos e do GIFE (Grupo de Institutos Fundações e Empresas), assim como em dois exemplos de organizações privadas, a eles estão associadas, e que, por isso, se alinham aos preceitos norteadores propostos por ambos sobre o modo como devem ser conduzidas as ações de RSE.

\section{A AMPLIAÇÃO DO PAPEL DE AGENTE SOCl- AL DO MERCADO}

No começo da década de 1990, iniciou-se no Brasil um intenso debate no âmbito do mercado e da sociedade civil sobre a importância das ações sociais de RSE na constituição do que seria uma nova forma de pensar programas de inserção social e de defesa de direitos à cidadania. Nessa época, soou bastante inusitado que empresas capitalistas estivessem se propondo a atuar em projetos sem fins lucrativos. Porém, com o passar dos anos, ações desse tipo tornaram-se corriqueiras. Vide os dados da segunda edição da Pesquisa Ação Social das Empresas realizada em 2006 pelo Instituto de Pesquisa Econômica Aplicada (IPEA) com o intuito de mapear a participação do setor empresarial em atividades sociais voltadas para as comunidades que possuam alguma carência social. Nessa pesquisa, cerca de $96 \%$ das grandes empresas no Brasil, isto é, aquelas com mais de qui- 
nhentos empregados, revelaram desenvolver algum tipo de ação social.

Hoje, esse debate parece ter chegado a um ponto crucial; nem tanto por se ter uma visão únivoca sobre o tema, mas, sobretudo, porque a posição que se tornou hegemônica é a que considera a RSE para além do mero cumprimento das obrigações legais. Nesse sentido, para nós, está claro que, a difusão do "ativismo social" empresarial no Brasil, desde meados dos anos de 1990, tem ocorrido graças aos esforços empreendidos por organizações como o GIFE (Grupo de Institutos Fundações e Empresas) ${ }^{2}$ na promoção de práticas de investimento social privado para projetos sociais, ambientais e culturais de interesse público; como o Instituto Ethos de Empresas e Responsabilidade Social $^{3}$ na disseminação da ideia de RSE junto ao meio empresarial; e como o Ibase (Instituto Brasileiro de Análises Sociais e Econômicas) por meio da campanha pela divulgação voluntária do balanço social ${ }^{4}$ empresarial, lançada em 1997 e de publicações ligadas à área de negócios, como, por exemplo, o Guia de Boa Cidadania Corporativa ${ }^{5}$ da Revista Exame, publicado desde 2001.

Os dados revelados pelo IPEA, orgão vinculado ao Governo Federal, atestam o crescimento da lógica da RSE em todas as regiões do Brasil (IPEA, 2006). A primeira edição da pesquisa, concluída em 2000, considerava um universo de quase 781.623 empresas privadas com um ou mais funcionários, sendo que a amostra utilizada na pesquisa foi de 9.140 empresas. Na segunda edi-

${ }^{2}$ Associação criada em 1995 com a finalidade de reunir empresas, institutos e fundações de origem privada que praticam investimento social por meio de repasse voluntário de recursos privados, de forma planejada, monitorada e sistemática (www.gife.org.br).

${ }^{3}$ Organização não-governamental criada em 1998 por empresários do setor privado, com o escopo principal de promover a mobilização, a sensibilização e a disponibilização de ajuda para o setor empresarial, no sentido de gerir os negócios de forma socialmente responsável www.ethos.org.br

${ }^{4}$ Demonstrativo publicado anualmente pela empresa, que reune um conjunto de informações sobre os projetos, benefícios e ações sociais dirigidas aos empregados, investidores, analistas de mercado, acionistas e à comunidade. É também considerado um instrumento estratégico para avaliar e multiplicar o exercício da responsabilidade social corporativa (www.ibase.br).

${ }^{5}$ No ano de 2007, passou a ser chamado de Guia Exame de Sustentabilidade. ção, concluída em 2004, o número de empresas privadas considerado foi de 870.953 , sendo que a amostra utilizada foi de 9.978 empresas. Em ambos os casos, o ponto de partida foi o cadastro mantido pelo Ministério do Trabalho e Emprego (MTE) e composto pela Relação Anual de Informações Sociais (RAIS) e pelo Cadastro de Empregados e Desempregados (CAGED). Os números da pesquisa revelaram que houve um crescimento de dez pontos percentuais no número de empresas que declaram desenvolver algum tipo de ação social voltada para a comunidade, saltando de $59 \%$ em 2000 para 69\% em 2004. Isso representa, considerando o universo estatístico da pesquisa, algo em torno de 600 mil empresas.

Nesse contexto, o fortalecimento do GIFE e do Instituto Ethos como protagonistas do espraiamento dessa lógica são exemplos dessa tendência de crescimento do "ativismo social" empresarial no Brasil. O primeiro, no início de suas atividades em 1995, contava com vinte e seis grandes organizações investidoras associadas. O número atualizado, referente ao mês de junho de 2008, é de cento e doze. Segundo o último Censo GIFE, ${ }^{6}$ referente aos anos de 2005 e 2006, os seus associados investiram cerca de $\mathrm{R} \$ 1,15$ bilhão em projetos sociais, culturais e ambientais feitos de forma planejada, monitorada e sistematizada. Isso equivale a $20 \%$ do que o setor privado nacional destina à área social - cerca de $\mathrm{R} \$ 4,7$ bilhões, segundo dados do IPEA (2006). A área priorizada pela rede para o investimento social privado é a educação, somando cerca de R $\$ 124$ milhões em 2005, com 2.894 entidades contempladas e, assim, 3.987.313 pessoas beneficiadas. Em 2005, as associadas do GIFE fizeram investimentos em projetos sociais, ambientais e culturais correspondentes a um montante de R $\$ 439.927$ milhões beneficiando um total de 5.938 entidades e 5.279 .912 pessoas.

Por sua vez, o Instituto Ethos, em dezembro de 2000, quando tinha apenas dois anos de existência, já contava com trezentos e quarenta empresas associadas, que, juntas, possuiam um

${ }^{6}$ O Censo GIFE 2005-2006 está disponível na íntegra no site (www.gife.org.br). 
faturamento correspondente a $22 \%$ do PIB nacional. Em julho de 2008, o número de empresas associadas totalizou 1.316, sendo que, em conjunto, elas representavam um faturamento de aproximadamente 35\% do PIB brasileiro e empregavam cerca de 2 milhões de pessoas. Necessário se faz dizer que, atualmente, o Instituto Ethos conta com empresas dos mais diferentes setores e portes. Isso porque, nos seus dois primeiros anos de atuação, o espraiamento da lógica da RSE esteve consideravelmente vinculado às grandes e médias empresas, devido à sua maior capacidade gerencial e de investimento, no que diz respeito à possibilidade de trabalhá-la estrategicamente, o que não implica dizer que todas efetivamente o façam. Em outras palavras, isso se deve à capacidade de essas empresas planejarem não apenas a promoção de mudanças na realidade social sobre a qual se pretende intervir, mas também de obterem algum tipo de retorno institucional. ${ }^{7}$ Todavia, nos últimos anos, a lógica da RSE também passou a ser disseminada junto a empresas de menor porte, que antes relutavam em assimilá-la com alegações de falta de dinheiro ou de conhecimento para agir. A esse respeito, o fundador e ex-presidente do Instituto Ethos, o empresário Oded Grajew, em entrevista à Revista Educação de dezembro de 2000, defendia que essas empresas,

Primeiro, devem primar pela exemplaridade [...]. As empresas podem mobilizar recursos - e isso não quer dizer só dinheiro. Recursos são equipamentos, materiais, serviços, conhecimentos, funcionários. Mesmo as pequenas empresas podem colocar esses recursos a serviço da comunidade. Posturas éticas servem para empresas de qualquer tipo e tamanho [...]. O maior problema das empresas pequenas é que elas não sabem como agir. Vamos encarar as pequenas e médias empresas como um desafio para 2001.

Dependendo da modalidade de exercício de RSE, isto é, se as ações sociais são do tipo comunitária, em que as empresas não atuam diretamente na gestão ou em projetos sociais próprios, atuam diretamente na gestão, elas podem obter os seguintes retornos institucionais: proteção e fortalecimento da imagem empresarial, em que as ações de comunicacão e marketing social assumem papel central; desenvolvimento de habilidades e competências do corpo funcional pela via de projetos de incentivo às práticas de voluntariado; maiores níveis de adesão à cultura organizacional da empresa por parte do corpo funcional, quando se considera os efeitos produzidos pelas práticas de resposabilidade social empresarial interna; e incentivos fiscais decorrentes de leis que geram retorno tributário.
Após intenso trabalho de divulgação de suas linhas de atuação ${ }^{8}$ junto ao meio empresarial, o Instituto Ethos conseguiu contornar essa situação. Constata-se o aumento da "representatividade no número de micro e pequenas empresas no rol de suas associadas", fato que, no caso das primeiras, é bastante significativo, pois, até o ano de 2000, nenhuma empresa desse porte era associada, como se pode verificar na Tabela abaixo.

Tabela 1 - Porte das empresas associadas do Instituto Ethos (2000 e 2008)

\begin{tabular}{l|c|c|c|c}
\hline \multicolumn{1}{c|}{ Porte } & $\begin{array}{c}\text { Total } \\
\mathbf{( 2 0 0 0 )}\end{array}$ & \% & $\begin{array}{c}\text { Total } \\
\mathbf{( 2 0 0 8 )}\end{array}$ & $\%$ \\
\hline Microempresa & - & - & 265 & 20,14 \\
\hline $\begin{array}{l}\text { Pequena } \\
\text { Empresa }\end{array}$ & 67 & 19,70 & 360 & 27,36 \\
\hline $\begin{array}{l}\text { Média } \\
\text { Empresa }\end{array}$ & 122 & 35,88 & 247 & 18,77 \\
\hline $\begin{array}{l}\text { Grande } \\
\text { Empresa }\end{array}$ & 151 & 44,41 & 444 & 33,74 \\
\hline
\end{tabular}

Fonte: Instituto Ethos de Empresas e Responsabilidade Social (jun., 2008)

O espraiamento da lógica da RSE também pode ser evidenciado pelo crescimento no número de microempresas que declararam investir em algum tipo de ação social para a comunidade, principalmente ações de voluntariado. Por isso, os números revelados pela pesquisa ${ }^{9}$ do IPEA confir-

${ }^{8}$ De um modo geral e resumido: 1) ampliação do movimento de RSE; 2) aprofundamento de práticas de RSE (Indicadores Ethos de RSE - incluindo versões para micro e pequenas empresas e alguns setores da economia promoção da publicação de balanços sociais e de sustentabilidade, produção de manuais práticos); 3) influência sobre mercados e seus atores mais importantes no sentido de criar um ambiente favorável à prática da RSE (desenvolvimento de critérios de investimentos socialmente responsáveis com fundos de pensão no Brasil, desenvolvimento de programa de políticas públicas e RSE, participação em diversos conselhos governamentais para discussão da agenda pública brasileira); 4) Articulação do movimento de RSE com políticas públicas: a) desenvolvimento de políticas para promover a RSE e desenvolver marcos legais; b) promoção da participação das empresas na pauta de políticas públicas do Instituto Ethos; 5) Produção de informação (pesquisa anual Empresas e Responsabilidade Social- Percepção e Tendências do Consumidor e coleta e divulgação de dados e casos das empresas).

${ }^{9} \mathrm{Na}$ pesquisa do IPEA, as microempresas são entendidas como aquelas que possuem de um a dez empregados. Definição não absolutamente coincidente com a utilizada pelo Serviço Brasileiro de Apoio às Micro e Pequenas Empresas (Sebrae), que as entende como aquelas que empregam até nove pessoas, no caso do comércio e serviços, ou até dezenove, no caso dos setores industrial ou de construção. Tampouco coincide com os critérios utilizados pela definição mais comum e mais utilizada, 
mam a tendência presente no próprio Instituto Ethos, já que houve um crescimento de $58 \%$ em 2000 para 68\% em 2004 na participação das microempresas no desenvolvimento de ações sociais junto a comunidade. Os pesquisadores do IPEA entendem esse aumento de participação muito mais como uma mudança ocorrida no comportamento das microempresas do que de mudanças ocorridas no comportamento de empresas de maior porte que já atuavam no desenvolvimento de ações sociais junto às comunidades.

Os números dos casos do GIFE e do Instituto Ethos evidenciam a ampliação do papel de agente social do mercado nos últimos anos, assim como os números apresentados pela pesquisa do IPEA. Tal tendência é atribuída pelo meio empresarial à crise do Estado Providência eà consequente perda de capacidade de o Estado investir sozinho na área social. Por pressões da sociedade civil, as empresas se veriam impelidas a contribuir para a produção de respostas aos problemas sociais e ambientais que afetam as realidades onde estão inseridas. O argumento é o de que, em não agindo assim, elas correm o risco de ter seus produtos e serviços boicotados pelos consumidores, uma vez que, em um mundo em que o acesso às informações tem sido mais fácil a possibilidade de eles adotarem uma postura mais cônscia e reativa às eventuais ações empresariais que produzam externalidades negativas para a sociedade. Essa seria uma variável a ser considerada no planejamento estratégico das empresas.

Desse modo, a RSE é pensada como uma estratégia de negócios num mercado em que a competitividade se intensifica. O engajamento da chamada "sociedade civil organizada" em torno de um discurso que demanda uma maior responsabilização das empresas ante alguns temas sociais ${ }^{10}$ estaria levando a uma readequação da

que está contida na Lei Geral para Micro e Pequenas Empresas promulgada em dezembro de 2006, na qual as microempresas são definidas como as que possuem um faturamento anual de, no máximo, R\$ $240 \mathrm{mil}$ por ano.

${ }^{10}$ Como, por exemplo, a transparência das informações na gestão empresarial. Vide o advento da governança corporativa, a maior preocupação com o meio ambiente e também com as comunidades locais que são afetadas pelas atividades das empresas. postura tradicional de enxergar os negócios. Para os entusiastas da RSE, a ideia não é o mercado substituir as funções do Estado, mas sim estabelecer parcerias intersetoriais entre os dois e o chamado terceiro setor na busca de soluções para os problemas sociais. Pois, "a responsabilidade social remete, em síntese, à constituição de uma cidadania organizacional no âmbito interno da empresa e à implementação de direitos sociais no âmbito externo" (Srour, 1998, p. 294-295).

Segundo Fischer (2002), os fatores cruciais para ofortalecimento da aliança entre Estado, mercado e terceiro setor são o grau de empoderamento ${ }^{11}$ atribuídopara cada um dos setores e a conscientização de que todos são igualmente importantes para o estreitamento de uma relação pautada na confiança. Assim, ao Estado caberia incentivar e regular as ações socialmente responsáveis; ao mercado, disponibilizar o seu know how em ferramentas de gestão na execução e avaliação dos projetos, visando a otimizar os resultados; e às organizações do terceiro setor, indicar os problemas sociais nos quais se deve investir, assim como incentivar a prática de ações de voluntariado. Isso porque, nessas áreas, considera-se que elas estejam qualificadas, mais especificamente as ONGs que, de modo intencional, passam a ser identificadas pelos atores do mercado como sinônimo de sociedade civil, istoé, como organizações capacitadas para uma interlocução técnica legítima, esvaziada de conteúdos "políticos". Nessa linha, a parceria intersetorial é entendida como fundamental para a consolidação da democracia, uma vez que a cooperação de organizações de diferentes tipos permitiria alcançar, de forma mais adequada, o desenvolvimento social. Vejamos o que diz o Instituto Ethos sobre isso:

A construção desse modelo requer uma nova dinâmica na relação entre Estado, mercado e sociedade civil, em que empresas e ONGs assumem papeis cada vez mais relevantes, sem que o Estado abdique do seu papel de protagonista na pro-

${ }^{11} \mathrm{Na}$ perspectiva da autora, o empoderamento é um processo por meio do qual pessoas ou grupos ganham poder para expressar e defender seus direitos, ampliar sua autoconfiança, identidade própria e autoestima, mas, sobretudo, é um processo que lhes permite exercer controle sobre suas relações pessoais e sociais. 
moção do desenvolvimento. O setor empresarial brasileiro tem condições privilegiadas de contribuir para esse processo: possui capacidade de mobilização, poder econômico e político, responsabilidade diante dos problemas sociais e ambientais e potencial para desenvolver ações passíveis de replicação por outros atores sociais (www.ethos.org.br).

Para os entusiastas da RSE, o chamado terceiro setor é entendido como o espaço composto por organizações privadas sem fins lucrativos, cuja atuaçãoé dirigida para finalidades coletivas ou públicas. Porém, como nos chama atenção Landim (1999), o termo Terceiro Setor carece de densidade conceitual como referência descritiva da realidade, uma vez que ele integra, de forma abrangente e sem fazer muita diferenciação, toda gama de organizações e instituições que substituem ou complementam o Estado no enfrentamento de questões sociais.

Desconsiderando a falta de densidade conceitual do termo, os arautos do fortalecimento do terceiro setor advogam que o encolhimento do Estado como meio de promoção de cidadania, no cenário político contemporâneo, é compensado pela ampliação do papel desempenhado pelo "novo associativismo civil”. Por sua vez, os entusiastas das ações de RSE pegam carona nesse discurso para tentar legitimar a postura de "ativismo social empresarial”, argumentando que, devido à pressão exercida pela "sociedade civil”, as empresas estão sendo obrigadas a assumir posturas socialmente mais responsáveis em relação ao conjunto de seus stakeholders. ${ }^{12}$

Argumentam que a nova forma de "associativismo civil" surgida a partir dos anos de 1980 vem se fortalecendo como esfera de manifestação legítima de grupos que lutam pelo reconhecimento de condições socioculturais idiossincráticas e pela autonomia em relação às dimensões institucionais do Estado e do mercado. Enfatizam

12 Termo que, no campo empresarial, designa qualquer indivíduo ou grupo que pode afetar, por meio de suas opiniões e acões, as atividades das empresas, ou que possam ser afetados pelas ações dessas. Esse termo surgiu como contraponto à noção de shareholders, que corresponde aos acionistas. O discurso da RSE apregoa que as preocupações das empresas não devem se restringir apenas aos interesses dos acionistas, mas também dos funcionários, fornecedores, consumidores comunidade, governo, etc. ainda que esses grupos não podem mais construir suas identidades fundamentalmente pela via do trabalho, visto que ele teria perdido sua centralidade no contexto do regime de acumulação flexível capitalista configurado após as crises dos oil shocks da década de 1970. Se, por um lado, a esfera institucional do trabalho ficaria enfraquecida como locus primordial da luta por direitos sociais, por outro, estariamos testemunhando o fortalecimento de uma esfera de interação comunicativa que permite aos mais diversos grupos sociais articularem-se e dialogarem não mais a partir de uma lógica de interesses particulares e específicos em disputa, mas sim objetivando consensos normativos respaldados socialmente e que representem o "interesse geral” (Habermas, 1999, 2001; Costa, 1997, 1999).

O “novo associativismo civil” teria como principais características: a) a horizontalidade das relações institucionais entre os atores sociais que estabelecem a interação comunicativa, sejam eles provenientes do Estado, do mercado ou da sociedade civil; b) a espontaneidade na formação das associações e nos vínculos entre seus membros; c) a legitimidade que emana da própria participação dos atores sociais, independentemente do vínculo profissional reconhecido por lei; d) a ação comunicativa que decorre da instauração de uma esfera pública na qual os atores sociais possam buscar o entendimento mútuo; e) e a intermediação societária de modo mais direto e próximo da sociedade, pois as organizações corporativas e o Estado possuem níveis de burocratização que tendem a conduzir as ações dos atores políticos mais para a defesa de interesses econômicos particulares e para o funcionamento da própria política institucional do que para a defesa dos interesses gerais (Avritzer, 1994, 1997).

Não estamos dizendo aqui que o fortalecimento do "associativismo civil" não instaure situações positivas na constituição de uma esfera pública mais diversificada, atuante e geradora de processos de inclusão social e defesa de questões ligadas ao meio ambiente, à diversidade cultural, às questões étnicas, de sexualidade e de genêro. Não temos dúvidas quanto à melhora qualitativa nes- 
ses aspectos. Porém é preciso considerar que o escopo da maioria das organizações que compõem a chamada sociedade civil organizada - aqui entenda-se especialmente as ONGs - está pautado em reivindicações pragmáticas, o que as faz adotar preceitos gerenciais para viabilizar a captação de recursos tanto junto ao Estado, quanto ao mercado. Desse modo, entendemos que essa situação conduz ao esvaziamento de posturas efetivamente dissenssuais. Dizemos isso porque é facilmente verificável o fato de as ONGs estarem cada vez mais submetidas aos termos da racionalidade instrumental do mercado. Essa situação se evidencia à medida que consideramos, assim como o faz Dagnino, que "a qualificação técnica de que as ONGs são portadoras parece constituir o fator central para explicar a importância que elas adquiriram no período mais recente.” (2002, p. 285).

Nesse sentido, tanto o GIFE quanto o Instituto Ethos consideram o papel das ONGs fundamental nesse novo modelo de desenvolvimento. Todavia empresas privadas ainda relutam em estabelecer parceriais com algumas ONGS, justamente porque algumas delas demonstram inabilidade para gerenciar adequadamente recursos, organizar informações, reduzir custos e avaliar os resultados dos projetos. Por conta disso, cada vez mais as ONGs são obrigadas a se profissionalizar. O conhecimento técnico a respeito do problema social que se quer resolver, por mais que decorra de uma intermediação societária mais direta, na lógica da RSE, não é mais considerado suficiente, mesmo quando fique caracterizado o caráter de "interesse geral" da demanda. Desse modo, os saberes técnicos-gerenciais, por estarem embebidos na racionalidade instrumental do mercado, tendem a colonizar a ação comunicativa que emerge dessa nova esfera pública. Não é por outra razão que a transferência de saberes gerenciais do mercado para as ONGs é tida como decisiva para o sucesso desse modelo.

Isso fica evidente, quando consideramos o fato de que o GIFE assim como o Instituto Ethos disponibilizam cursos sobre ferramentas de gestão voltados para o desenvolvimento de projetos sociais, como, por exemplo: a) cenário social e le- gislação para o Terceiro Setor; b) elaboração de projetos; c) avaliação e análise de recursos; d) comunicação e marketing para organizações da sociedade civil; e) sustentabilidade e captação de recursos; f) desenvolvimento e gestão de programas de voluntariado; e g) gestão de parceriais e alianças. No caso específico do Instituto Ethos, as seis ferramentas consideradas básicas são: Primeiros Passos, Matriz de Evidências, Guia de Balanço Social ou Relatório de Sustentabilidade, Localizador de Ferramentas, Banco de Práticas e Indicadores Ethos. ${ }^{13}$ No meio empresarial, esses saberes e ferramentas são cada vez mais entendidos como necessários para o gerenciamento adequado das relações com ONGs e comunidades beneficiadas pelos recursos disponibilizados por empresas, institutos ou fundações de origem privada.

No que concerne ao crescimento das ONGs nas últimas décadas e à sua conseguinte identificação como sinônimo de "sociedade civil”, não podemos perder de vista o legado marxista-gramsciano que considera a sociedade civil como um lugar onde se manifestam contradições das mais diversas, dentre as quais as lutas de classes e os conflitos entre os mais variados grupos e camadas sociais. Desta perspectiva, Isabel Monal defende que:

... a vitalidade destes movimentos associativos designados ou autointitulados por muitos como "sociedade civil" -, bem como as posições progressistas que geralmente adotam, geraram numa

${ }^{13}$ Essa ferramenta, em específico, merece um maior esclarecimento, já que foi desenvolvida para o planejamento e monitoramento da gestão socialmente responsável. A estruturação desses indicadores ocorre por intermédio de um questionário organizado em sete temas, quais sejam: valores e transparência; público interno; meioambiente; fornecedores; consumidores e clientes; comunidade; e governo e sociedade. Esse questionário basicamente consiste em verificar, por meio de três tipos de indicadores, intitulados indicadores de profundidade, binários e quantitativos, o estágio de RSE no qual a empresa avaliada se encontra: 1) estágio básico, no qual as ações da empresa são reativas às obrigações legais; 2) estágio intermediário, no qual as ações mantêm uma postura defensiva sobre os temas, mas já começam a encminhar mudanças e avanços em relação à conformidade de suas práticas; 3) estágio avançado, no qual já são reconhecidos os benefícios de ir além da conformidade legal, preparando-se para novas pressões reguladoras do mercado, da sociedade etc.; 4) estágio proativo, no qual a empresa atingiu padrões considerados de excelência em suas práticas que envolvem fornecedores, consumidores, clientes, a comunidade e influencia políticas públicas de interesse da sociedade (Indicadores Ethos de Responsabilidade Social, 2006). 
certa esquerda uma idealização da sociedade civil; ao mesmo tempo, manisfesta-se uma tendência a restringir tal conceito apenas às ONGs e a vê-las como polo positivo do binômio Estado/ sociedade civil. Uma certa mitologia está em processo de construção [...]. Esta idealização tende a ignorar que a sociedade civil (mesmo se for indevidamente restringida às ONGs) não é homogênea, nem de um ponto de vista classista nem ideológico (2003, p. 192).

Apesar dessa importante ressalva, não desconhecemos que nas sociedades capitalistas exista a possibilidade de mudanças no campo político que conduzam uma melhora nas condições objetivas de vida. Porém, para que isso ocorra, é preciso considerar, como o faz Bourdieu (1998), o fato de o Estado ser um espaço ambíguo, que não pode ser visto como um simples instrumento a serviço dos grupos dominantes. E, não obstante ser neutro, ele pode desenvolver certa autonomia e força a partir de uma condição de antiguidade, como lugar de incorporação e registro de conquistas sociais em suas estruturas. Ou seja, se o Estado é percebido como fragilizado para a tarefa de promover o acesso aos bens públicos à luz de uma perspectiva política neoliberal, isso se deve muito mais a uma construção discursiva que lhe imputa essa condição do que propriamente por impossibilidades que lhes sejam inerentes. Como nos lembra Bourdieu (2002), esse discurso não possui a neutralidade que seus defensores alegam, até porque sua origem é socialmente bem definida, qual seja, a moral americana da poupança e da ascese ecônomica, que constitui o cerne da noção de selfhelp (se virar por conta própria). Assim, o discurso de sua permanência ou não em determinada condição de existência material pode ser entendido como uma sociodiceia, isto é, como uma narrativa que funciona no sentido de justificar a sociedade tal como ela é. Nesse caso, uma configuração societal produzida pelo estágio capitalista de acumulação flexível e pelas políticas de inspiração neoliberal. Isso sem falar que tais políticas estariam baseadas em alguns postulados distorcidos da teoria econômica:

... o primeiro postulado é que a economia é um domínio à parte, separado do mundo social, governado por leis naturais, universais, que os governos nẫo devem contrariar. O segundo postula- do diz que o mercado é a instância capaz de organizar de forma ótima as relações sociais, as trocas, a produção, etc., e também de garantir uma distribuição equitativa. Faz-se uma equação entre mercado e democracia. O terceiro postulado afirma que a globalização exige a redução das despesas do Estado, a diminuição das despesas sociais - ou seja, o retorno ao laissez faire - e a supressão de tudo o que possa turvar a lógica pura do mercado. Os direitos sociais em matéria de emprego, previdência social, são vistos como onerosos e disfuncionais (Bourdieu, 2002, p. 26).

A incorporação dessa narrativa conduz os indivíduos à crença de que a transformação de suas condições materiais, assim como da realidade social que os cerca, são tarefas que competem exclusivamente a si mesmos, porém de modo isolado, ou, no máximo, agregado a outros indivíduos que comunguem de valores e interesses semelhantes. Alicerçada em uma ideologia da competência, ela cria um cenário propício para a disseminação de duas ideias aparentemente sem ligação, mas que, de fato, são as faces de uma mesma moeda: 1) o indivíduo como responsável pela sua empregabilidade e 2) a solidariedade social via ações de voluntariado e filantropia como um substitutivo das ações de grupos politicamente organizados ${ }^{14}$ na busca pela instauração de direitos à cidadania. No nosso modo de entender, essa última ideia é a que dá suporte ao discurso de que as empresas, assim como os indivíduos, devem se responsabilizar pelos seus atos ante a sociedade.

Como demonstra Ivo (2001), nos termos da política neoliberal, é preciso "mobilizar o potencial dos pobres”, isto é, aproveitar as relações sociais existentes nas comunidades e canalizá-las para a resolução tanto do problema material da pobreza quanto da participação e integração social. A participação e a capacidade de organização dos pobres na apresentação de suas demandas e na produção de soluções para suas necessidades básicas são tidas como uma condição efetiva que pode ser considerada tanto do ponto de vista positivo quanto negativo. Do ponto de vista positivo, aproveita-se o potencial combativo e de resistência dos pobres,

${ }^{14}$ Entenda-se aqui, partidos políticos, sindicatos, entidades corporativas e grupos de interesses que manifestam sua atuação política na esfera institucional do Estado. 
visando a transformá-los em um "ativo" que lhes faça superar a condição de vulnerabilidade social e, por conseguinte, lhes permita a integração ao mercado e a superação da condição de pobreza. Nessa perspectiva, leva-se em conta apenas "aqueles pobres viáveis, os "bons" pobres, os capazes de transformarem-se em cidadãos-consumidores integrados à sociedade de mercado" (2001, p. 71). Do ponto de vista negativo, essa perspectiva:

... localiza a pobreza como residual ao progresso da sociedade industrial e como situaçã̃o incompatível com o crescimento e a ordem democrática. Na linha dessa percepção avançam políticas repressivas ou de gestão da miséria e da assistência, muitas vezes articuladas às ações caritativas de entidades e organizações filantrópicas e hoje às ONGs (Ivo, 2001, p. 71).

Diante desse quadro, não é mero acaso o discurso da RSE posicionar-se a favor do desenvolvimento de projetos sociais que encarnem a lógica do "é melhor ensinar a pescar do que dar o peixe". Nessa linha, ajuda efetiva seria entendida como aquela que visa a gerar uma condição de autonomia das comunidades pela via da capacitação dos beneficiados para a gestão dos problemas socioeconômicos por eles enfrentados. Para nós, a responsabilização do pobre pela permanência ou não em determinada condição de existência material é inerente à lógica da RSE; a maior evidência disso seria a ênfase dada à transferência de conhecimentos gerenciais para as ONGs e comunidades beneficiadas.

\section{A OTIMIZAÇÃO DA “PARTE DOS QUE NÃO TÊM PARTE"}

Seguindo uma linha de pensamento que considera o "ativismo social” das empresas vinculado à lógica hegemônica do capitalismo global, Paoli (2002) entende a RSE como um tipo questionável de promoção de cidadania. Ela inicialmente faz referência ao quadro político e econômico brasileiro dos anos de 1990, em que o Estado brasileiro, devido à implementação de políticas de inspiração neoliberais, passou a fragilizar-se na sua função de investir em políticas públicas de proteção e garantia dos direitos sociais. A partir desse quadro, ela faz referência ao surgimento relativamente recente de um tipo de "sociedade civil" que inicialmente emergiu mais fortemente pela via dos movimentos sociais autônomos e politizados, em que o mote era o ativismo político pela cidadania e justiça social, e que, nos diais atuais, teria tido sua força deslocada para um ativismo civil voltado para a solidariedade social. Enquanto o caminho dos movimentos sociais implica a demanda direta por bens públicos, o caminho das ONGs opta por representar as demandas sociais de forma pragmática, a partir de formulações técnicas com governos e prescindindo de uma base ampliada de participação popular. Nessa segunda linha, inserem-se os programas de RSE. A tese defendida por Paoli é que

... não obstante, os programas sociais produzidos
pelo ativismo social empresarial apresentarem
dimensões bastante positivas, os critérios pró-
prios à noção de globalização hegemônica pro-
postos neste projeto - a expulsão de populaçóes
de um contrato social estável, a aleatoriedade
seletiva no tempo e o espaço no qual as ações
acontecem, a tentativa de construir uma respos-
ta a exclusões através unicamente da lógica pas-
teurizada do capital transnacional -, como tam-
bém os critérios sobre o que vem a ser a dimen-
são pública e política do agir político, parecem
indicar que este caso é mais um contraexemplo
de uma ação democrática participativa do que
uma ação contra-hegemônica, podendo comple-
mentar-se, sem contradições insuperáveis, aos
arranjos neoliberais (2002, p. 379).

Independentemente dos arranjos neoliberais impostos - com a conversão do Estado em esfera gestora de carências e necessidades sociais e não em esfera pública de manifestação do dissenso na qual é instaurada a partilha do sensível que define a parcela que cabe a cada parte da sociedade (Rancière, 1996a, 1996b), - no Brasil, como advoga Oliveira (1999), a anulação da política como esfera de manifestação do dissenso via um complexo de violência e de proibição da fala é inerente à formação do espaço político.

Para a maioria dos brasileiros, a democracia representativa tornou-se a máscara que esconde uma condição de destituição de direitos. É possí- 
vel dizer que um dos fatores que ajudam a dar continuidade a essa situação é uma certa aversão extremada ao caráter dissensual da política, que parte considerável dos grupos dominantes historicamente evidenciam ter no cenário da política institucional brasileira. Essa condição do fazer política foi interpretada por autores como Sérgio Buarque de Holanda, Caio Prado Jr., Florestan Fernandes e Celso Furtado, entre outros, a partir de categorias como patrimonialismo, revolução pelo alto e incompatibilidade radical entre domínio burguês e democracia. A promiscuidade entre o público e o privado, largamente difundida na cena política brasileira, é um elemento exacerbador da lógica excludente imposta pela política neoliberal ${ }^{15}$ implementada nos anos de 1990.

Esses fatores, segundo Chauí (1999), contribuiram de modo significativo para os patamares extremos de desigualdades econômicas e sociais existentes no Brasil contemporâneo. Como resultado, temos um cenário de encolhimento do espaço público e de alargamento do espaço privado que, aliados ao desemprego estrutural e à exclusão sociopolítica, polarizaram a sociedade brasileira entre a carência e o privilégio. Nesse sentido, Chauí nos chama a atenção para o fato de que

... uma carência é sempre particular e específica, não conseguindo generalizar-se num interesse comum nem universalizar-se num direito, e um privilégio, por definição, é sempre específico e particular, não podendo generalizar-se num interesse comum nem universalizar-se num direito sem deixar de ser privilégio. Na medida em que prevalecem carências e privilégios e os direitos não conseguem instituir-se, inexistem condições para a cidadania e a democracia (2002, p. 43).

A configuração de um campo fértil para a disseminação de ações sociais de "associativismo civil” e de RSE é indicada como uma saída "possível” para a crise do Estado brasileiro. Ante esse quadro, as ações individualizadas de solidariedade social de cunho pragmático, voltadas funda-

${ }^{15}$ Aqui se entenda o conjunto de princípios ordenados para o ajuste estrutural do mercado, que consiste basicamente nas seguintes regras básicas: liberalização do mercado e do sistema financeiro, fixação dos preços pelo mercado, fim da inflação ("estabilidade macroeconômica") e privatizações. mentalmente para a superação de carências e de necessidades localizadas, sobrepõem-se às ações coletivas de engajamento político que objetivam a consolidação de direitos sociais que possam dar forma a uma comunidade política constituída de sujeitos sociais ativos e não de indivíduos que se convertem em meros receptáculos da racionalidade instrumental do mercado. Desse modo, tenta-se configurar uma forma sofisticada de eliminação do dissenso. Tal situação não conduz a uma ampliação efetiva da esfera pública, isso porque, como demonstra Rancière (1996a, 1996b), o dissenso não é a guerra de todos contra todos, mas sim as situações de conflito ordenadas, de discussão e argumentação, não entre parceiros já constituídos, mas entre sujeitos sociais que demonstrem a existência de um objeto sobre o qual é preciso argumentar visando à reordenação da “partilha do sensível”.

Na década de 1990, a privatização se impôs no Brasil como resposta à falência do Estado, decorrente do aumento da dívida pública interna, haja vista o intenso processo de privatizações de empresas estatais. ${ }^{16} \mathrm{~A}$ argumentação utilizada foi a de que o mercado empresta dinheiro ao Estado e, por esta razão, esse último deveria ser administrado como uma extensão do primeiro. Porém, como demonstrou Oliveira (1999), o processo real se dá de modo inverso, já que a riqueza pública, em forma de fundos, sustenta a reprodutibilidade do capital privado. O discurso neoliberal dissemina a ideia de que o agravamento do desemprego e a intensificação dos problemas sociais são consequências da incapacidade do Estado de lidar com essas questões. A omissão do fato de que o desemprego estrutural e a instalação da precariedade como condição de vida são inerentes ao

${ }^{16}$ No período de 1991a maio de 2000, ocorreu no Brasil a privatização de um total de sessenta e cinco empresas e participações acionárias estatais federais nos seguintes setores: elétrico, petroquímico, de mineração, portuário, financeiro, de informática e de malhas ferroviárias. Muitos estados e municípios foram compelidos pelo Governo Federal, mediante condicionamentos financeiros, privatizar seus ativos. Entre essas privatizações, destacam-se as das siderúrgicas Usiminas, privatizada em outubro de 91, e CSN (Companhia Siderúrgica Nacional), que deixou de ser estatal em abril de 1993, a mineradora Vale do Rio Doce, privatizada em maio de 1997, e a fabricante de aeronaves Embraer, que passou pelo processo de venda em 1994. 
modelo de acumulação flexível que caracteriza o atual estágio de desenvolvimento capitalista é um fator crucial no processo de disseminação da ideia de que uma aliança intersetorial deve ser formada para combater as mazelas sociais. A RSE é um dos remédios receitados pela racionalidade do mercado no sentido de melhorar os resultados no desenvolvimento de políticas públicas. Nesse sentido, o Instituto Ethos posiciona-se da seguinte maneira:

... considera o momento propício para promover o avanço do movimento de responsabilidade social rumo à construção desse novo modelo de desenvolvimento. Atento às oportunidades que a conjuntura atual oferece, vem realizando, com a participação ativa de seus associados e das empresas em geral, a articulação, de modo suprapartidário, das práticas de responsabilidade social das empresas com políticas públicas dos governos federal, estaduais e municipais voltadas para inclusão social, erradicação da pobreza e da fome, combate à corrupção e desenvolvimento ambiental (www.ethos.org.br).

O grifo é nosso, pois entendemos que esse discurso tenta impor, de modo subliminar, que não há "sensível" a ser "partilhado"; o argumento de que inexistem outros caminhos institui um real que reflete a racionalidade do mercado. A RSE é uma das evidências do processo de descontratualização social a que se referem Oliveira (1999) e Santos (1999). O projeto de igualdade política e justiça social sucumbe ante um discurso de não-existência de alternativas viáveis fora da lógica do mercado. Dessa feita, as ações sociais de RSE não passam de otimização da "parte dos que não têm parte". Como nos chama atenção Paoli:

Em um duplo movimento para fora de si mesma, a "empresa-cidadã" realiza eficientemente sua beneficência localizada e produz, para o espaço público da opinião e para o espaço privado de seus pares, a perspectiva de uma presença ampliada, legítima, do próprio poder social do capital (2002, p. 407).

Um bom exemplo dessa situação é a experiência do projeto Banco de Valor ${ }^{17}$ do Banco ABN

\footnotetext{
${ }^{17}$ Relato integral dessa experiência pode ser encontrado no Guia de Boa Cidadania Corporativa, de 2003, da Revista Exame.
}

Amro Real, associado tanto do GIFE quanto do Instituto Ethos. Em 2001, o banco passou a promover reuniões para o conjunto dos seus quinze maiores empregadores de terceirizados no sentido de criar o acesso a um fórum de discussão permanente sobre responsabilidade social. O objetivo, segundo um diretor do banco, era formar uma "corrente do bem" que viesse a trazer benefícios também para quem não estivesse vinculado diretamente à instituição. A ideia surgiu após se observar que alguns terceirizados faziam refeições de forma improvisada no estacionamento da sede do banco, em meio à fumaça que era expelida dos automóveis.

Contudo, é o relato da proprietária de uma empresa de motofrete que terceirizava serviços para o banco que melhor caracteriza a representatividade do exemplo. Isso porque, antes de participar das reuniões, ela revelou que não tinha nenhuma familiaridade com palavras como "transparência" $e$ "público interno". Tanto ela quanto os duzentos e quinze motociclistas de sua empresa viam o discurso da RSE com desconfiança. Após a participação nesse fórum, as discussões sobre o assunto tornaram-se rotina na empresa, inclusive foi criado um código de ética que coíbe agressividade no trânsito e estimula o voluntariado. Todos os motociclistas passaram por cursos de direção defensiva e de noções de poluição ambiental. O resultado prático foi a queda da média de quinze para zero acidentes anuais que envolviam resgate. Na época desse relato, a empresária também fez referência ao fato de ter fechado um contrato de fornecimento de combustível com um posto de gasolina no qual havia uma cláusula de interrupção caso esse viesse a empregar mão-de-obra infantil. Segundo ela, "os projetos exigem tempo e dedicação, mas não arrancam um tostão do caixa”.

No ano de 2003, o programa já atingia sessenta fornecedores e exigiu, em sua fase inicial, 100 mil reais em investimentos. Porém, nas palavras do diretor responsável pelo projeto, "para saúde de nossas relações corporativas, o ganho foi incalculável". Além do que, segundo ele, "foi emocionante deflagrar um processo que saiu de nossas mãos e passou a caminhar sozinho". A incorpo- 
ração do discurso da RSE pela empresária e a sensação de satisfação do diretor do banco caracterizam bem a perspectiva de presença ampliada e legítima do poder social do capital à qual Paoli se refere.

Obviamente, não devemos cair na armadilha de que a incorporação desses discursos se processa sem qualquer tipo de mediação cognitiva feita pelos atores sociais envolvidos. A esse respeito, nos alinhamos ao entendimento de Giddens (1991), no que concerne ao fato de o atual estágio do projeto da modernidade se caracterizar como modernidade reflexiva. Isso porque entendemos que os indivíduos, como atores sociais, são dotados de uma capacidade de cognição que se nutre dos conhecimentos significativos provenientes não apenas de suas experiências sociais, mas também das condições e das consequências daquilo que fazem em suas vidas cotidianas. Desse modo, para nós, toda e qualquer ação social deve ser compreendida com base em um olhar analítico que leve em consideração os conhecimentos que os próprios atores sociais possuem, pois, na interação comunicativa entre eles, são feitas apropriações e reavaliações de acordo com certos conhecimentos prévios das condições e das consequências que os indivíduos possuem sobre os discursos e práticas com os quais se deparam em suas vidas cotidianas.

Todavia, apesar da reflexividade que está contida no modo como os atores sociais podem se apropriar do discurso do "ativismo social' empresarial, acreditamos que os arautos da RSE, não obstante apregoarem o contrário do que aqui é dito, não podem negar o fato de serem tais ações norteadas pela racionalidade do mercado e que, por isso, de racionalidade comunicativa só possuem a aparência. Em outras palavras, a imposição dessa lógica discursiva cria a impressão de que a salvação da sociedade só pode se dar pela via dos modelos de gestão concebidos, testados e aprovados pelo mercado.

Para nós, está bastante claro que tais modelos funcionam baseados nos princípios da redução de custos e da otimização de resultados, o que os torna relativamente complicados quanto à operacionalização - senão nos termos da própria lógica que os impõem - para instruir os parâmetros de execução, acompanhamento e avaliação dos resultados de ações sociais que visem a promover o acesso a uma condição de cidadania efetiva, na qual os indíviduos não sejam apenas reconhecidos nos seus direitos e deveres como membros de um projeto comum de sociedade, mas que também tenham suas falas reconhecidas, por mais dissensuais que o sejam, em esferas públicas realmente ampliadas.

Essa situação nos remete a um antigo provérbio latino: Quis custodiet ipsos custodes? ${ }^{18} \mathrm{~A}$ resposta mais provável seria uma esfera pública realmente ampliada, na qual todos os grupos sociais que se sintam sofredores de um dano possam, por via de falas dissenssuais, se manifestar e reivindicar a parte que lhes deveria caber no todo social. Isso porque, como advoga Rancière, “... é em nome do dano que lhe é causado pelas outras partes que o povo se identifica com o todo da comunidade” (Rancière, 1996b, p. 24). Do contrário, o que resta é a política como "polícia”, isto é, um mero conjunto de operações realizadas pelo Estado, pelo mercado e, atualmente, até mesmo por uma parte considerável da chamada "sociedade civil organizada", no sentido de otimizar "a parte dos que não têm parte”. O que, no caso brasileiro, soa muito mais sombrio se considerarmos as sociedades europeias nas quais o chamado Estado do Bem estar social deixou algum legado.

\section{UMA EXTERNALIDADE DO REGIME DE ACU- MULAÇÃO FLEXÍVEL}

Desde a recessão econômica mundial do início da década de 1970 e da crise do petróleo em 1973 que a exarcerbou, uma forma de acumulação

\footnotetext{
${ }^{18}$ Quem guarda os guardiões? Questionamento feito pelo poeta romano Jovenal (século II D.C) no seu livro VI das Sátiras, embora o contexto original se refira a saber de que maneira um marido pode prender sua esposa astuta em casa para previnir o adultério. A resposta seria: deixando-a sob a observação de um quardião. Daí a origem do questionamento. A partir de então, essa frase passou a ser aplicada largamente para referir-se ao modo como as pessoas e as organizações atuam contra a desonestidade e a corrupção, especialmente na esfera pública.
} 
capitalista mais flexível foi sendo imposta de modo concomitante ao enfraquecimento do Estado-providência que caracterizou o período de vigência do modelo taylor-fordista de produção, modelo esse que se mostrou rígido demais para superar a crise pela qual passava o capitalismo. Como decorrência desse quadro, as décadas de 1970 e 1980 caracterizaram-se como períodos conturbados de reestruturação econômica e de reajustamento social e político, o que fez tomar forma um regime de acumulação flexível que se contrapõe à rigidez do período fordista. Nas palavras de Harvey, tal regime "apoia-se na flexibilidade dos processos de trabalho, dos mercados de trabalho, dos produtos e padrões de consumo" (2004, p. 140).

A partir de então, no universo empresarial, tem ocorrido uma intensificação do trabalho devido à exigência de multifuncionalidade dos trabalhadores ante ao processo produtivo, bem como processos frequentes de reestruturação que diminuem o corpo funcional com vínculo empregatício. ${ }^{19}$ Além disso, testemunhamos, nas últimas duas décadas, o enfraquecimento do poder de barganha dos sindicatos, o que tem levado a um processo de supressão de direitos trabalhistas e previdenciários que, na maioria dos casos, não são privilégios como quer fazer acreditar o discurso de inspiração neoliberal, mas conquistas de diversas lutas da classe trabalhadora no decorrer do século XX.

Por sua vez, na atual configuração do capitalismo, o fortalecimento dos mercados financeiros em detrimento do Estado-Nação, no que concerne à indicação dos caminhos possíveis tanto para o desenvolvimento econômico quanto para o social, tem deslocado os processos decisórios cada vez mais para as esferas locais. Isto é, desloca-se a tomada de decisões para esferas de maior proximidade sociopolítica das empresas, esferas nas quais elas possam mais diretamente exercer seu poder de influência.

${ }^{19}$ É preciso considerar que o vínculo empregatício não caracterizava apenas a celebração de um tipo de relação jurídica que permitia o acesso a toda uma rede de protecão social aos trabalhadores, mas também a possibilidade de eles planejarem o futuro com uma maior margem de segurança, devido à hegemonia do contrato de trabalho por tempo indeterminado.
A necessidade desse modelo de acumulação flexível é justificada no meio empresarial pelo argumento de que a maior complexidade dos mercados globais exige formas de ação mais eficazes em um contexto de acirrada competitividade. Desse modo, valores como desburocratização, inovação, diversificação, valorização de recursos humanos como meio de aumentar a competitividade e desmanche do Estado-providência são tidos como imprescindíveis para a sobrevivência empresarial.

Do ponto de vista empresarial, a mudança de um modelo de produção mais rígido para um mais flexível parece trazer mais benefícios do que malefícios. Todavia, do ponto de vista social, devido ao modelo de especialização flexível que se materializa na fábrica enxuta e se alimenta de constantes inovações tecnológicas, o desemprego estrutural se apresenta como uma externalidade negativa. No entanto, Castel (2003) nos chama atenção para o fato de ser o desemprego apenas a manifestação mais visível de uma profunda transformação do emprego, pois a precarização do trabalho é uma outra característica dessa situação, em suas palavras: "menos espetacular, porém mais importante". A precarização se manifesta na perda gradativa de hegemonia do contrato de trabalho por tempo indeterminado que caracterizou o período taylorista-fordista, no qual fora instituída uma sociedade salarial em que os trabalhadores podiam vislumbrar certa estabilidade em sua vida, devido à rede de proteções sociais existente.

Para Castel (2003), a flexibilização produtiva instaura uma nova questão social, na qual a precarização do trabalho é o principal fator gerador da crescente pauperização de boa parte da classe trabalhadora. Sob o ângulo do trabalho, três pontos de cristalização dessa questão podem ser percebidos: 1) a desestabilização dos estáveis, em decorrência da redução dos contratos por tempo indeterminado; 2) a instalação da precariedade, por conta da condição de "interino permanente"; e 3) o déficit de lugares ocupáveis na estrutura social, entendidos aqui por posições às quais estão associados uma utilidade social e um reconhecimento público. Uma consequência fundamental dessa 
nova questão social é o fato de que, para categorias cada vez mais numerosas da população economicamente ativa, a identidade pelo trabalho estaria perdida, caracterizando-se, desse modo, o que ele denomina de processo de “desfiliação”, isto é, de perda dos suportes sociais que sustentam a condição de cidadania em sociedades democráticas e o desengajamento material e simbólico dos indivíduos diante dos vínculos sociais. Em sentido durkheimiano, isso conduz a uma perda gradativa de um tipo de integração que decorre da sensação de pertencimento a uma sociedade formada por um todo de elementos interdependentes. No caso específico do terceiro ponto, tem-se como decorrência o surgimento de um conjunto de indivíduos que Castel identifica como os "supranumerários", isto é, os não integrados e não integráveis.

No que diz respeito as ações de RSE desenvolvidas no sentido de gerar trabalho e renda no contexto de um regime de acumulação flexível que configura uma situação crescente de exclusão e de pauperização social, é possível perceber que essas ações podem ser entendidas como uma externalidade ${ }^{20}$ da própria flexibilização produtiva. Em uma metáfora um tanto quanto simplista, mas quiçá ilustrativa, é como se estivéssemos diante da serpente que nos inocula o veneno, mas que se oferece espontaneamente para produzir o soro antiofídico que irá nos "salvar": o empreendedorismo. O mais interessante, e talvez por isso pensemos ser ilustrativa a metáfora, é que o antídodo é obtido a partir do sangue da força de trabalho que tornou-se desnecessária. Porém, agora, o que se armazena nãoé mais um exército industrial de reserva, mas sim potenciais candidatos à condição de supranumerários, caso o soro do empreendedorismo não surta os efeitos positivos esperados.

${ }^{20}$ Aqui entendida como efeitos positivos ou negativos, em termos de custos e benefícios gerados pelas atividades de produção ou consumo exercidas por um agente econômico e que atingem os demais agentes, sem que eles tenham oportunidade de impedi-los ou a obrigação de pagá-los. Portanto, externalidades é um termo que se refere ao impacto de uma decisão sobre aqueles que não participaram dessa decisão. Elas podem ser negativas, quando geram custos aos demais agentes, ou podem ser positivas, quando eles, de modo involuntário, delas se beneficiam.
E aqui a ilustração fica por conta do caso da siderúrgica Acesita, ${ }^{21}$ também associada do GIFE e do Instituto Ethos. A sua planta industrial está localizada no Vale do Aço, no estado de Minas Gerais, mais precisamente na cidade de Timóteo, onde os pouco mais de 75 mil habitantes vivem em uma economia local que gravita em torno da empresa desde o ano de sua fundação, em 1944. ${ }^{22}$ Em outubro de 1992, período de sua privatização, a Acesita tinha 9 mil empregados. Após os programas de reestruturação realizados nos anos que se seguiram, seu quadro funcional foi reduzido em quase dois terços, contando, no ano de 2005, com 3.148 empregados e 2.090 terceirizados. ${ }^{23}$

Devido à criticidade do processo de enxugamento funcional e o impacto socioeconômico que ele ocasionaria, a alta administração da Acesita, cônscia do papel central que a empresa desempenhava para a região, criou, em 1994, a Fundação Acesita para o Desenvolvimento Social. ${ }^{24} \mathrm{~A}$ criação dessa fundação, na percepção da nova administração, decorreu da necessidade de modificar o caráter 'paternalista' que caracterizara a atuação social da empresa, quando ela era estatal. Desse modo, o suposto ‘paternalismo' teve de ser colocado de lado em prol do negócio e da própria sociedade. Nas palavras do então presidente da Acesita, Luiz Anibal de Lima Fernandes, "revimos nosso relacionamento" e, por isso, "decidimos criar uma fundação e desenvolver um plano para a cidade". O cerne da estratégia é o fortalecimento das ONGs da região, para que elas se tornem sustentáveis e venham a ajudar o poder público na resolução de problemas comunitários que possam conduzir ao

${ }^{21}$ Atualmente, a companhia se chama Arcelor Mittal Inox Brasil, produto da fusão da Mittal Steel Company e da Arcelor. Em 2006, a empresa siderúrgica Mittal Steel comprou 191,3 milhões das ações da Arcelor Brasil. Dessa forma, a Mittal assumiu o controle de $96 \%$ das ações do grupo Arcelor, antigo controlador da Acesita.

${ }^{22}$ Para se ter uma ideia da presença dominante da empresa na região, logo após o início de suas operações, em abril de 1949, o munícipio passou a ser chamado por muitas pessoas de Acesita, sendo que, até hoje, há uma confusão entre essa denominação e o nome oficial, que é Timóteo.

${ }^{23}$ Dados obtidos a partir do Balanço Social da Empresa publicado no ano de 2005.

${ }^{24} \mathrm{O}$ relato completo desse caso pode ser visto no Guia de Boa Cidadania Corporativa, Exame de 2003. 
aumento do Índice de Desenvolvimento Humano (IDH) dos munícipios da região, pois, apesar de Timóteo possuir um IDH de 0,831 - o maior do Vale do Aço, o quinto melhor de Minas Gerais e o $127^{\circ}$ do país-, dezesseis dos vinte seis munícipios da região ainda têm IDH abaixo de 0.700 .

Nesse sentido, a fundação criou, em 1999, o programa Vale Cidadania, no qual o principal trunfo era a capacitação dos dirigentes das ONGs por meio de cursos de administração financeira, comunicação, marketing e planejamento estratégico, entre outros - todos pagos pela Fundação Acesita. Segundo a gerente do programa Vale Cidadania, "com isso, as entidades aprendem a formatar seus projetos e vendê-los aos financiadores”. E ela continua: "a autossustentação vem daí". Em outras palavras, é preciso que as ONGs estejam capacitadas para obter outras fontes de financiamento, não apenas da Fundação Acesita.

Nessa linha, a Fundação Acesita desenvolve mais de cinquenta projetos sociais na região, sendo que um em especial nos chama a atenção, principalmente quando consideramos as consequências da nova questão social à qual se refere Castel (2003) e o discurso de "responsabilização dos pobres" pela sua permanência ou não na condição de pobreza. Esse projeto intitula-se "Instituto de Artesãos" e está vinculado ao plano de desenvolvimento da cidade de Timóteo pela via do Instituto do Inox, esse último uma tentativa de incentivar o empreendedorismo e reduzir as consequências do fim da garantia de emprego vitalício típico do período em que a empresa era estatal. Trata-se de um projeto de geração de trabalho e renda que visa à capacitação de pessoas aposentadas para trabalharem como autônomos na produção e comercialização de peças artesanais elaboradas com aço inox.

Segundo Fischer (2002), em um estudo de caso realizado sobre a Fundação Acesita, esse é o único projeto no qual a empresa possui um interesse específico, pois pressupõe o incremento do consumo do aço inox por ela produzido. Desse modo, a fundação encarregou-se da criação do espaço e da disponibilização dos equipamentos para a capacitação técnica dos interessados, permitindo, inclusive, aos que ainda não possuíssem capital para iniciar o seu próprio negócio, a possibilidade de permanecerem trabalhando no local. A fundação também contratou os serviços de entidades como o Senai (Serviço Nacional de Aprendizagem Industrial) e o Sebrae (Serviço de Apoio às Micro e Pequenas Empresas) para ministrarem cursos e seminários sobre desenvolvimento empresarial.

Desde 1993, auxiliado pela fundação Acesita, o programa Instituto do Inox deu origem a mais de 80 microempresas e foram criados cerca de mil novos postos de trabalho. Todavia é preciso lembrar que o estatuto social desses postos de trabalho não trazem consigo o conjunto de benefícios que caracterizam os postos de trabalho existentes em uma empresa do porte da Acesita. Ao atuar diretamente no desenvolvimento de políticas públicas na região do Vale do Aço, a empresa passa a imagem de comprometimento com o desenvolvimento regional, porém é preciso que se considere que essa postura carrega consigo a necessidade de garantir um ambiente menos hostil, necessário à sustentabilidade dos seus negócios. As parcerias estabelecidas com os poderes públicos locais e com ONGs vinculadas às comunidades objetivam conferir a legitimidade necessária ao seu poder de influência na esfera local.

No nosso entendimento, o fomento dessa lógica de desenvolvimento de projetos sociais voltados para geração de trabalho e renda tem como forças impulsionadoras: $1^{\circ}$ ) o fato de que, no atual estágio de desenvolvimento capitalista, uma fábrica, para ser competitiva, deve almejar ser o mais enxuta possível, isto é, deve inspirar-se no conceito do engenheiro Taiichi Ohno (1997), responsável pela criação do modelo de produção japonês da Toyota, para o qual "o conceito de economia é indissociável da busca de redução de efetivos e de redução de custos"; $2^{\circ}$ ) as estratégias políticas de inspiração neoliberal, que veem, no encolhimento do papel do Estado como provedor do bem estar social, uma exigência para o bom funcionamento dos mercados, esses últimos entendidos como esferas adequadas para garantir o vigor e a saúde socioeconômica em tempos de economia global. 
Para os arautos dessa lógica, liberdade de mercado é agir sem as amarras de demandas sociais coletivas que possam impedir a livre expansão dos mercados. Por isso, os indivíduos devem ser incentivados a assumir a responsabilidade pela geração de trabalho e renda por meio de projetos sociais que os capacitem como empreendedores.

Nas palavras de Telles, a corrosão dos direitos gerada por essa configuração societal,

Além da evidente fragilização das condições de trabalho e de vida da maioria, a destituição dos direitos - ou, no caso brasileiro, a recusa de direitos que nem mesmo chegaram a se efetivar significa também a erosão das mediações políticas entre o mundo social e as esferas públicas, de tal modo que estas se descaracterizam como esferas de explicitação de conflitos e dissenso, de representação e negociação; é por via dessa destituição e dessa erosão, dos direitos e das esferas de representação, que se ergue esse consenso que parece hoje quase inabalável de que o mercado é o único e exclusivo princípio estruturador da sociedade e da política, que diante de seus imperativos não há nada a fazer, a não ser a administração técnica de suas exigências, que a sociedade deve a ele se ajustar e que os indivíduos, agora desvencilhados das proteções tutelares dos direitos podem finalmente provar suas energias e capacidades empreendedoras (1998, p. 25-26).

A descrição feita por Telles (1998, 1999, 2000) corresponde ao encolhimento da cena política que se evidencia pela restrição da dimensão transgressora da palavra que deveria reivindicar e pronunciar os direitos daqueles que são sofredores dos danos concernentes à fragilização da rede de proteção social que a condição de assalariamento permitiu, se não acessível para todos os trabalhadores, como ocorrido no caso brasileiro, pelo menos situação almejável como horizonte de direitos sociais a serem conquistados. As consequências desse encolhimento são a inviabilização da construção de alternativas na dinâmica conflituosa da vida social e o estreitamento do horizonte do possível e do pensável - situações que levam a um processo de demissão do pensamento como possibilidade fundadora de um mundo comum.

\section{CONSIDERAÇÕES FINAIS}

A realidade social, como atualmente se configura no Brasil, não parece corresponder a uma era de indeterminações, na qual a vida ficou absolutamente imprevisível e indeterminada, e, como tal, impossível de se fazer política, como advoga Oliveira (2003). O que parece ocorrer é que, nos dias atuais, estamos vivendo sob a égide de uma forma de sociabilidade que se afasta cada vez mais das ideias de igualdade e justiça social como configuradoras de um mundo comum para todos aqueles que não conseguem acessar o "bem estar social” oportunizado pelo mercado. Por isso, tais cidadãos são impelidos a se sujeitar, com frequência, aos serviços públicos precários e de má qualidade oferecidos pelo Estado e ao desmantelamento de todo um conjunto de direitos sociais ligados ao emprego formal - como conquistas da classe trabalhadora no decorrer do século XX -, decorrentes da imposição de uma agenda política de inspiração neoliberal que dá suporte ao modelo de acumulação flexível capitalista.

Nessa nova forma de sociabilidade, o precário e o instável tendem a se naturalizar como princípios ordenadores da vida social, pois os discursos de inspiração neoliberal lhes atribuem novas significações e gradativamente esvaziam o caráter nocivo que possuem no imaginário daqueles que nunca vivenciaram e que não mais terão a possibilidade de vivenciar alguns importantes direitos sociais ligados ao mundo do trabalho. Todavia esses discursos não fazem o caráter pernicioso dessa condição se desvanecer da vida dos destituídos, apenas a escamoteia insidiosamente com um discurso de responsabilização individual, fazendo-os crer que os lugares por eles ocupados na estrutura social ou são uma decorrência do simples mérito de cada um, ou da simples falta dele, ou pior: são uma mera questão de sorte ou azar. Assim, o recrudescimento da violência dos que não têm parte no todo social e a reação também violenta e recrudescida dos que têm parte são resultados bastante previsíveis e determinados. Só que a violência dos que têm parte traz consigo um 
sério agravante: o suporte do aparato coercitivo do Estado. Dado esse cenário, a política não se torna impossível, mas apenas passa a ser pensada explicitamente como um simples exercício de gestão de carências e necessidades localizadas. Ou seja, "polícia”, no sentido que lhe confere Rancière.

Diante dos fatos que se apresentam, o real se converte no possível que está contido nas falas constitutivas do discurso do capitalismo globalizado. Os atores sociais, que não são os produtores desse discurso, não são pensados como sujeitos capazes de produzir adequadamente suas estratégias de vida ante às exigências impostas pela atual configuração do capitalismo, mas sim, como meros receptáculos de um discurso que os desapropria da possibilidade de uma fala dissensual sobre outros possíveis. Isto é, se, por um lado, os projetos de RSE podem trazer benefícios econômicos e sociais àqueles para os quais são dirigidos, por outro, parece condená-los à condição de meros condutores das diretrizes pensadas por aqueles que se apresentam como dotados de "legitimidade" para indicar o caminho do possível. E aqui, podemos dizer, se enquadram os esforços empreendidos pelo GIFE, pelo Instituto Ethos e por todas as organizações, fundações e empresas privadas que se inspiram nessa lógica.

Para nós, o espraiamento da lógica da RSE se intensifica a partir do encolhimento da esfera pública como locus de manifestação do dissenso. As ações de RSE são uma manifestação clara de simples exercício de gestão de carências e necessidades locais, como inclusive procuramos demostrar em um estudo de caso sobre as ações de RSE desenvolvidas pela maior indústria produtora de alumínio primário individual do Brasil, localizada no estado do Pará (Barbosa, 2007). Afirmamos isso pois essas ações se apresentam, na maioria dos casos, mesmo que isso seja negado pelo discurso das parcerias intersetoriais, como um substitutivo do Estado na formulação de soluções organizativas para os problemas vivenciados pelas comunidades beneficiadas. Dito doutro modo, as ações de RSE não se expressam como política, no sentido de reconhecerem cidadãos dotados de direitos, mas sim como gestão, uma vez que aquilo que elas reconhecem são clientelas carentes de assistência.

Em uma democracia realmente participativa, a sociedade civil não tem condições de se fortalecer de fato, quando se vê submetida a uma ação colonizadora empreendida pela racionalidade instrumental do mercado. Tampouco quando se torna um simples sinônimo do que Hannah Arendt (2005) chamou de esfera social, onde o que importa é a mera reprodução da vida em sociedade a partir de ações que objetivam simplesmente suprimir situações de carências e necessidades. Desse modo, a sociedade civil tem poucas chances de funcionar como uma esfera na qual seja possível não apenas fiscalizar de modo efetivo a atuação do Estado e do mercado, mas, acima de tudo, de se apresentar como uma esfera na qual possam ser engendradas alternativas que superem as disfuncionalidades e as perspectivas autocentradas de ambos, até mesmo porque, em não atuando com a devida autonomia diante dos dois, a sociedade civil, em tempos de domínio da lógica do capital financeiro, tenderá a assistir à conversão do Estado num mero legitimador dos interesses do mercado.

A grande tarefa que nos é apresentada atualmente consiste em tornar possível a desconstrução de uma lógica de inclusão social que se apresenta quase como um sinônimo de inclusão pela via dos acessos ao crédito e ao consumo, e que, por essa razão, consegue ser tão sedutora aos olhos de muitos, mesmo que amplamente excludente para a maioria desses muitos.

(Recebido para publicação em julho de 2008) (Aceito em janeiro de 2009)

\section{REFERÊNCIAS}

ARENDT, Hannah. A condição humana. 10.ed. Rio de Janeiro: Forense Universitária. 2005. 352 p.

AVRITZER, Leonardo. Modelos de sociedade civil: uma análise específica do caso brasileiro. In: (Org). Sociedade civil e democratização. Belo Horizonte: Del Rey, 1994. Um desenho institucional para o novo associativismo. Lua Nova, São Paulo, CEDEC, n.39, p. 149-174, 1997.

BARBOSA, Attila Magno e Silva. Cidadania empresarial: o ardil da destituição do dissenso. Ciências Sociais Unisinos, São Leopoldo, v. 43, n. 3, p. 267-276, set./dez., 2007. 
BOURDIEU, Pierre. Contrafogos: táticas para enfrentar a invasão neoliberal. Rio de Janeiro: Jorge Zahar Editor, 1998. $152 \mathrm{p}$.

Pierre Bourdieu entrevistado por Maria Andréa Loyola. Rio de Janeiro: Ed. UERJ, 2002. 98 p. (Coleção pensamento contemporâneo,1)

CASTEL, Robert. As metamorfoses da questão social: uma crônica do salário. 4.ed. Petrópolis: Vozes. 2003. 616 p.

CHAUÍ, Marilena. Ideologia neoliberal e universidade. In OLIVEIRA, Francisco de; PAOLI, Maria Célia (Org.) Os sentidos da democracia: políticas do dissenso e hegemonia global. Petrópolis: Vozes; Brasília: Nedic, 1999. p. 27-51.

COSTA, Sérgio. La esfera pública y las mediaciones entre cultura y política: el caso de Brasil. Metapolítica. México, v. 3, n. 9. 1999 .

Movimentos sociais, democratização e a cons-

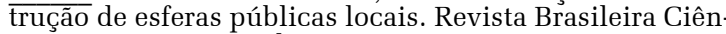
cias Sociais, São Paulo, v. 12, n. 35, p. 121-134. 1997.

DAGNINO, Evelina. Sociedade Civil, espaços públicos e a construção democrática no Brasil: limites e possibilidades. In: DAGNINO, Evelina (Org.) Sociedade civil e espaços públicos no Brasil. São Paulo: Paz e Terra. 2002. p.279-301.

FISCHER, Rosa Maria. O desafio da colaboração: práticas de responsabilidade social entre empresas e terceiro setor. São Paulo: Ed. Gente, 2002. 176 p.

GIDDENS, Anthony. As consequências da modernidade. São Paulo: UNESP, 1991. 180 p.

GIFE. Censo GIFE 2005-2006. São Paulo: Ed. Jogo de Amarelhinha, 2006. 120 p.

HABERMAS, Jürgen. Teoria de la acción comunicativa. Racionalidad de la acción y racionalización social. Madrid, Taurus. Tomo I. 1999. 517 p.

. Técnica e ciência como ideologia. Lisboa: Edições 70. 2001. 147 p.

HARVEY, David. Condição pós-moderna. 13.ed. São Paulo: Loyola. 2004. 352 p.

IVO, Anete Brito Leal. Metamorfoses da questão democrática: governabilidade e pobreza. Buenos Aires: CLACSO. 2001. $208 \mathrm{p}$.

IPEA. A iniciativa privada e o espírito público: a evolucão da ação social das empresas privadas no Brasil. Brasília: 2006. $36 \mathrm{p}$.

LANDIM, Leilah. Notas em torno do Terceiro Setor e outras expressões estratégicas. O Social em Questão, Rio de Janeiro, OUC, v. 3, n. 4, p. 61-98, jul./dez., 1999.
MONAL, Isabel. Gramsci, a sociedade civil e os grupos subalternos. In: COUTINHO, Carlos Nelson; TEIXEIRA Andreá de Paula (Org.) Ler Gramsci, entender a realidade. Rio de Janeiro: Civilização Brasileira, 2003. p. 189-200.

OHNO, Taiichi. O sistema Toyota de produção: além da produção em larga escala. São Paulo: Bookman Companhia, 1997. $152 \mathrm{p}$.

OLIVEIRA, Francisco. Privatização do público, destituicão da fala e anulação da política: o totalitarismo neoliberal. In: OLIVEIRA, Franciso; PAOLI, Maria Célia (Org.) Os sentidos da democracia. Políticas do dissenso e hegemonia global. São Paulo: Vozes, NEDIC/FAPESP, 1999. p. 55-82.

A dominação globalizada: estrutura e dinâmica da dominacão burguesa no Brasil. In: BASUALDO, Eduardo M.; ARCEO, Enrique (Org.) Neoliberalismo e sectores dominantes: tendências globales y experiências nacionales. Buenos Aires: CLACSO, 2003. p. 265-291.

PAOLI, Maria Célia. Empresas e responsabilidade social: os enredamentos da cidadania no Brasil. In: SANTOS, Boaventura de Souza (Org.) Democratizar a democraciaos caminhos da democracia participativa. Rio de Janeiro: Civilização Brasileira, 2002. p. 373-418.

RANCIÈRE, Jacques. O dissenso. In: NOVAES, Adauto (Org). A crise da razão. São Paulo: Companhia das Letras, 1996a. p.367-382.

144 p. O desentendimento. São Paulo: Editora 34, 1996b.

SANTOS, Boaventura de Souza. Reinventar a democracia: entre o pré-contratualismo e o pós-contratualismo. In: OLIVEIRA Francisco; PAOLI, Maria Célia (Org.) Os sentidos da democracia Políticas do dissenso e hegemonia global. São Paulo: Vozes, NEDIC/FAPESP, 1999. p.83-129. SROUR, Robert Henry. Poder, cultura e ética nas organizações. São Paulo: Campus, 1998. 344 p.

TELLES, V. S. No fio da navalha: entre carências e direitos. In: BAVA, Silvio Caccia (Org.) Estudos, formação assessoria em políticas sociais. Programa de Renda Mínima no Brasil: impactos e potencialidades. [S.l.], 1998. p.9-36. Mimeo.

Direitos sociais: afinal do que se trata? Belo Horizonte: Ed. UFMG, 1999. 196p.

A modernização vista de baixo.São Paulo: Editora 34,2000 . p. $1-26$ 


\section{THE "SOCIAL ACTIVISM" OF BUSINESSES AND ITS BIAS ANTIDISSENSION}

\author{
Attila Magno e Silva Barbosa
}

This paper consists of an analysis of the business social responsibility (RSE in Portuguese) as a means of suppression of politics as a sphere of dissent manifestation. The performance of organizations such as Group of Institutes, Foundations and Companies (in Portuguese, GIFE) and of the Instituto Ethos de Empresas e Responsabilidade Social (Ethos Institute of Companies and Social Responsability) has been contributing significantly to the legitimation of RSE actions as sources of solutions for social problems. In this sense, we understand that the ideological foundation of that situation lies in the discourse that seeks to minimize the role of the State as promoting agent of social development and to attribute to the poor, as individuals, the responsibility for their permanence in or out poverty. For no other reason, such practices promote the beneficiaries' involvement in the solutions of their problems, what seems to be positive from the point of view of creation of a sphere of more democratic decision-making. However, it is necessary to have in mind that these beneficiaries' knowledges are only considered if emptied of effectively dissentious postures.

KEYWORDS: business social responsibility, business social activism, civilian society, new civilian associativism, dissent.

\section{L' “ACTIVISME SOCIAL” DES ENTREPRISES ET SON BIAIS ANTI-DISSENSUEL}

\author{
Attila Magno e Silva Barbosa
}

Ce travail analyse la responsabilité sociale des entreprises (RSE) comme moyen de suppression de la politique en tant que sphère de manifestation du dissensus. Le travail des organisations telle que le GIFE (Groupe d'Instituts, de Fondations et d'Entreprises) et de l'Institut Ethos d'Entreprises et Responsabilité Sociale a beaucoup contribué à la légitimation des actions de la RSE en tant que source productrice de solutions pour les problèmes sociaux. Dans ce sens, il semblerait que le fondement idéologique de cette situation se trouve dans un discours qui vise à diminuer le rôle de l'Etat comme agent promoteur de développement social et d'attribuer aux pauvres, en tant qu'individus, la responsabilité du maintien ou non de leur condition de pauvreté. Pour les mêmes raisons, de telles pratiques permettent l'engagement des bénéficiaires dans la solution de leurs problèmes, ce qui semble être positif du point de vue de la création d'une sphère de prise de décisions plus démocratique. Néanmoins, il ne faut pas oublier que les savoirs de ces bénéficiaires ne sont pris en compte qu'à partir d'une perte de postures effectivement dissensuelles.

Mots-CLÉs: responsabilité sociale d'entreprise, activisme social d'entreprise, société civile, nouvelle associativité civile, dissensus.

Attila Magno e Silva Barbosa - Doutorando do Programa de Pós-Graduação em Sociologia da Universidade Federal de São Carlos - UFSCar. Mestre em Antropologia Social pela Universidade Federal do Pará. Integra o Núcleo de Pesquisa Estudos do Trabalho e Mobilidade Social (UFSCar), desenvolvendo pesquisas na área de sociologia do trabalho e sociologia política. Suas mais recentes publicações, são: Cidadania empresarial: o ardil da destituição do dissenso. Ciências Sociais Unisinos, v.43, p.267-276, 2007; O futebol e a sociedade global: uma reavaliação da identidade sociocultural brasileira. Sociedade e Cultura (UFG), Goiânia, v. 10, p.173-186, 2007. 